\title{
A Case of Massive Oropharyngeal Bleeding from Pseudoaneurysm of Superior Thyroid Artery Associated with Parapharyngeal Abscess
}

\author{
Yong-Il Cheon ${ }^{1}$, Chang-Ki Woo ${ }^{1}$, Chan-Hwi Park ${ }^{1}$, and Yun-Sung Lim ${ }^{2}$ \\ ${ }^{1}$ Department of Otorhinolaryngology-Head and Neck Surgery, Pusan National University School of Medicine, Busan; and \\ ${ }^{2}$ Department of Otorhinolaryngology-Head and Neck Surgery, Ilsan Hospital, Dongguk University, Goyang, Korea
}

\section{부인두 농양에서 기원한 상갑상선 동맥 가성동맥류에서 발생한 다량의 구인두 출혈 1예 \\ 천용일 ${ }^{1}$ 우창기 ${ }^{1} \cdot$ 박찬휘 $^{1} \cdot$ 임윤성 ${ }^{2}$ \\ 부산대학교 의학전문대학원 이비인후과학교실, ${ }^{1}$ 동국대학교 일산병원 이비인후과학교실 ${ }^{2}$}

\author{
Received March 9, 2014 \\ Revised June 8, 2014 \\ Accepted June 9, 2014 \\ Address for correspondence \\ Yun-Sung Lim, MD, PhD \\ Department of Otorhinolaryngology- \\ Head and Neck Surgery, \\ Ilsan Hospital, \\ Dongguk University, \\ 27 Dongguk-ro, Ilsandong-gu, \\ Goyang 410-773, Korea \\ Tel $+82-31-961-7439$ \\ Fax $+82-31-961-7427$ \\ E-mail splash1@daum.net
}

\begin{abstract}
Parapharyngeal abscess is relatively common but it can cause life-threatening complications like internal jugular vein thrombophlebitis, septic shock, airway obstruction, and mediastinitis. The diagnosis is dependent on physical examination, endoscopic view, and CT and MR imaging. The treatment is antibiotics but sometimes incision and drainage are necessary. Pseudoaneurysm in deep neck space is very rare and mainly caused by trauma, postoperative state of head and neck surgery and radiation therapy. We herein report a case of massive oropharyngeal bleeding from pseudoaneurysm of the superior thyroid artery associated with parapharyngeal abscess with a review of related literature. Korean J Otorhinolaryngol-Head Neck Surg 2015;58(2):124-9
\end{abstract}

Key Words Parapharyngeal abscess · Pseudoaneurysm · Superior thyroid artery.

\section{서 론}

심경부 감염은 경부의 근막층과 잠재적인 공간에서 발생하 는 감염이며 생명을 위협할 수 있으므로 적극적인 치료가 필요 하다. 심경부 농양은 편도주위 농양, 후인두 농양, 부인두 농양 으로 분류되며 부인두 농양은 편도나 편도주위 농양이 상인 두 수축근을 똟고 부인두 공간을 침범하면서 발생한다. ${ }^{1,2}$ 진 단은 문진과 신체진찰, 컴퓨터단층촬영, 후두내시경 등을 이 용하며 항생제 및 수액 요법과 필요에 따른 절개배농을 시행할 수 있다.

농양은 경동맥막을 따라 종격동까지 파급될 수 있으며 경정 맥 혈전증, 패혈증 쇼크, 상기도 폐쇄, 목동맥 가성동맥류, 농 흥, 심막염 등 심각한 합병증이 동반되기도 하므로 임상적으로 중요하다.) 상갑상선 동맥에서 기원한 가성동맥류의 출혈은 주
로 경부절제술 또는 방사선 치료 과거력이 있는 환자에서 발생 하며 즉각적인 대처가 필요하다.

그러나 본 교실에서는 드물게 편도주위 농양에서 파급된 부 인두 농양이 진행함에 따라 상갑상선 동맥의 출혈이 발생하였 고 그 출혈 부위에서 가성동맥류가 형성, 구강 내 다량 출혈이 발생하여 코일 색전술을 통해 치료한 증례를 보고자 한다.

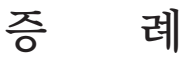

2012년 3월 뇌경색 진단을 받아 스텐트 시술을 받고 아스피 린을 복용하면서 4년간 당뇨 및 혈압 치료를 받던 44세 여자 환자가 발열과 인후통을 주소로 2012년 6월 10일 응급실로 내 원하였다. 당뇨는 약물 복용 중이었으나 혈액검사상 당화혈색 소(hemoglobin A1c)는 $10 \%$ 로 잘 조절되지 않는 상태였다. 경 
부 컴퓨터단층촬영(CT)상 편도선염에 따른 편도비대와 소량 의 인두 농양이 관찰되어 약물치료와 향후 수술의 필요성에 대 하여 설명하였으나 환자는 연고지 관계로 집 근처 인근 2차 병 원에서 치료받기를 원하여 전원하였다(Fig. 1).

이후 인근 병원의 기록에 의하면 입원하여 광범위 항생제 정 주를 통해 증상호전을 보이던 중 전원한 지 10 일경부터 피가 섞인 객담(blood tinged sputum)이 발생하였으나 뚜렷한 출 혈 발생부위를 찾을 수 없었던 바, 전원한 지 2주째인 2012년 6월 24일 오후 5시경 소주 3컵 분량, 6월 25일 새벽 소주 4컵 분량의 구인두 출혈을 주소로 다시 본원 응급실로 전원되었 다. 당시 시행한 경부 CT상 농양이 파열되어 우측 경부 및 부 인두 공간, 구강 내에서 관찰되는 상태였고 후두내시경에서는 파열된 농양 주위로 출혈이 확인되었다(Fig. $2 \mathrm{~A}, \mathrm{~B}$, and C).
이에 즉시 아스피린 복용을 중단하였고 환자는 초음파 유 도하에 경피적 카테터(transcutaneous pigtail catheter) 삽입 술을 시행받았으며 항생제를 투여하며 경과를 관찰하였다. 이 후 추가 출혈은 관찰되지 않았으며 빠르게 호전되는 임상경과 를 보였다(Fig. 2D). 그러나 술후 3일간 경과 관찰 중 6월 28일 저녁 갑자기 다량의 토혈이 발생하였으며 출혈 및 혈종으로 인 해 호흡곤란 증상이 발생하였다. 측정한 헤모글로빈(hemoglobin) 수치도 3일 전의 $11.7 \mathrm{~g} / \mathrm{dL}$ 에서 $7.1 \mathrm{~g} / \mathrm{dL}$ 로 감소하는 등 다량의 동맥혈 출혈 의심하에 응급으로 저녁 10시경 중재적 경동맥 혈관조영술(interventional carotid angiography)을 시행하였다. 혈관조영술에서 농양 내에 상갑상선 동맥 기원의 가성동맥류가 관찰되었고 코일을 이용한 색전술을 시행하였 다(Fig. 3).
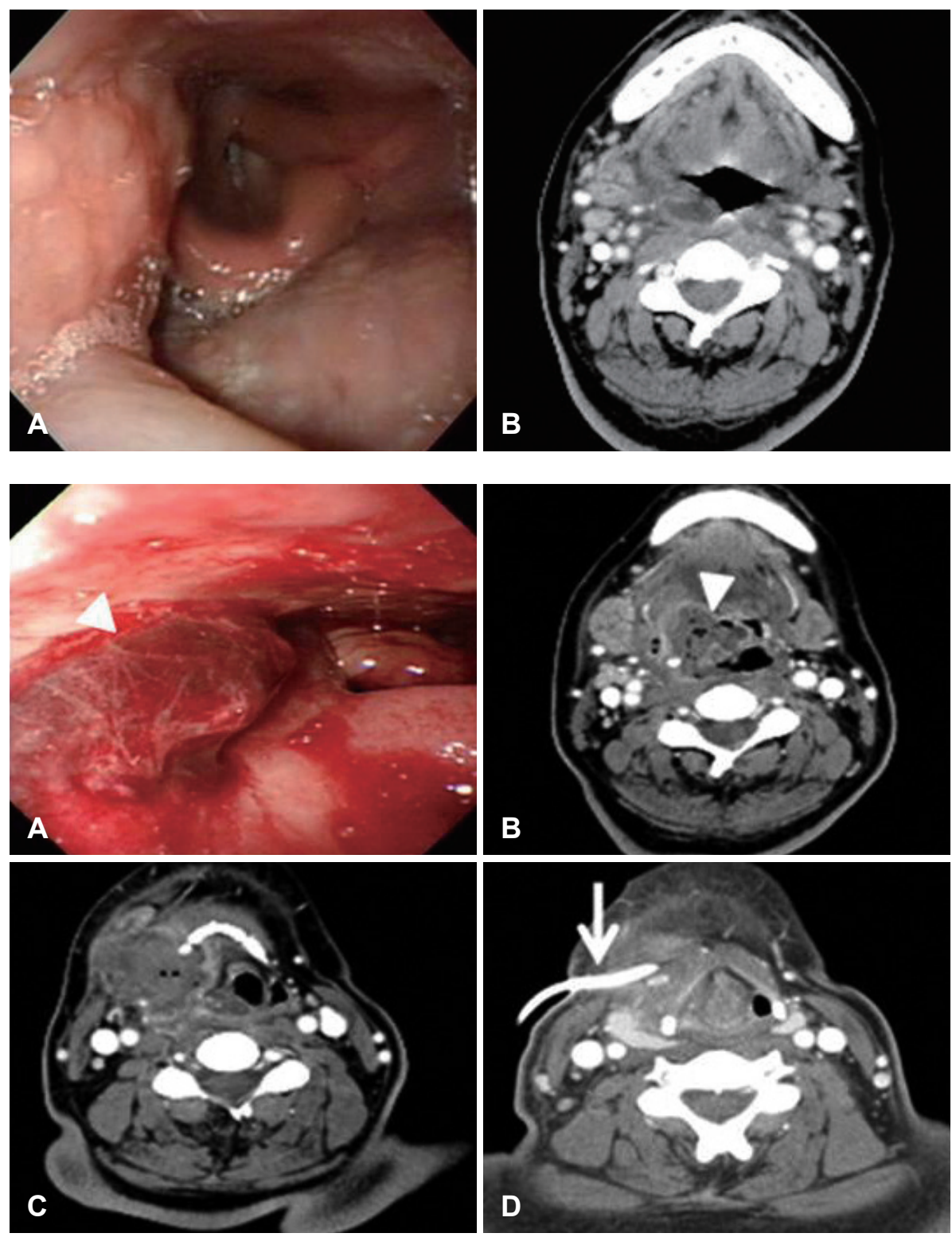
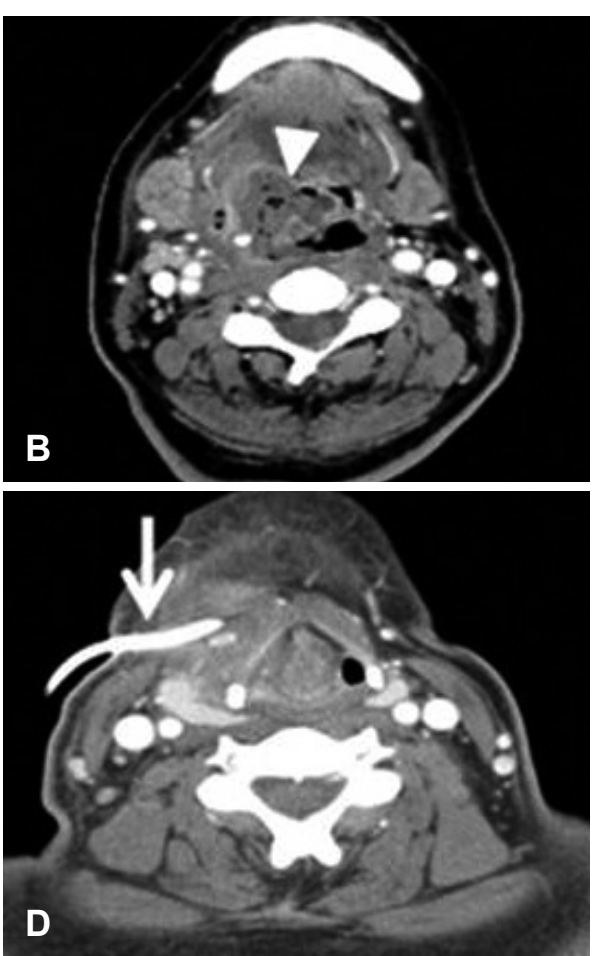

Fig. 1. Initial fiberoscopic view and neck CT. Endoscopic (A) and computed tomographic images (B) demonstrate the accumulation of abscess in pharyngeal space.

Fig. 2. Follow-up fiberoscopic view and neck CT at 2nd visit. Endoscopic image demonstrates right ruptured parapharyngeal abscess (A). Serial CT images exhibit the extent of parapharyngeal abscess (B and $C$ ). Sono-guided draining catheter was inserted to abscess pocket and there is no evidence of residual fluid accumulation (D). 

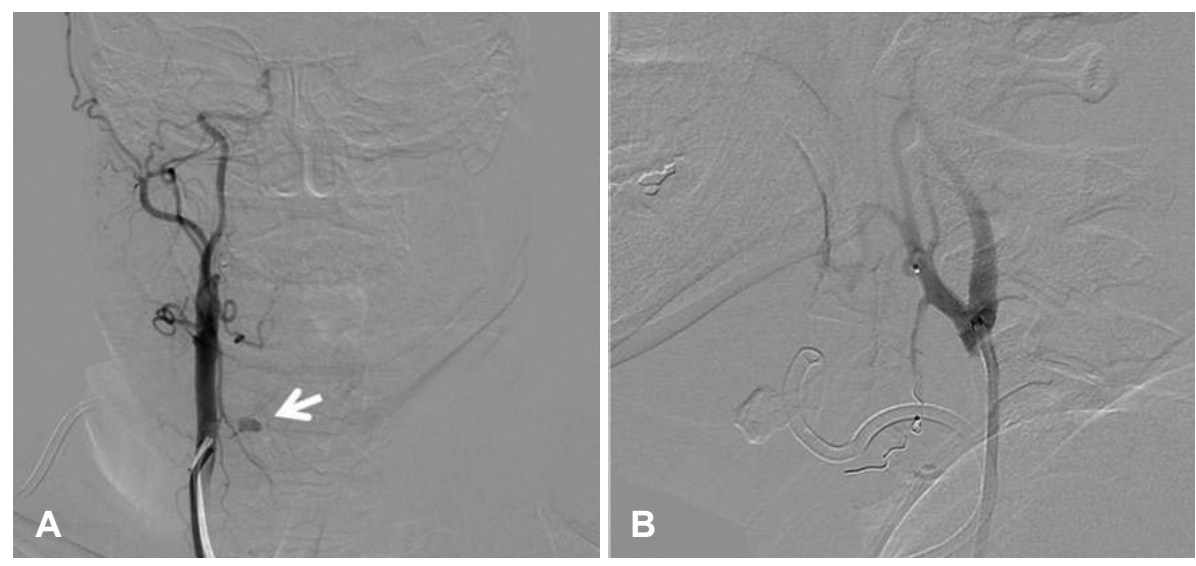

Fig. 3. Angiography for the embloization. Pseudoaneurysm (white arrow) arising from superior thyroid artery with contrast extravasation is noted (A). Coil embolization was successfully done without complication (Tornado $3 / 2$ coils, Gelform slurry) (B).
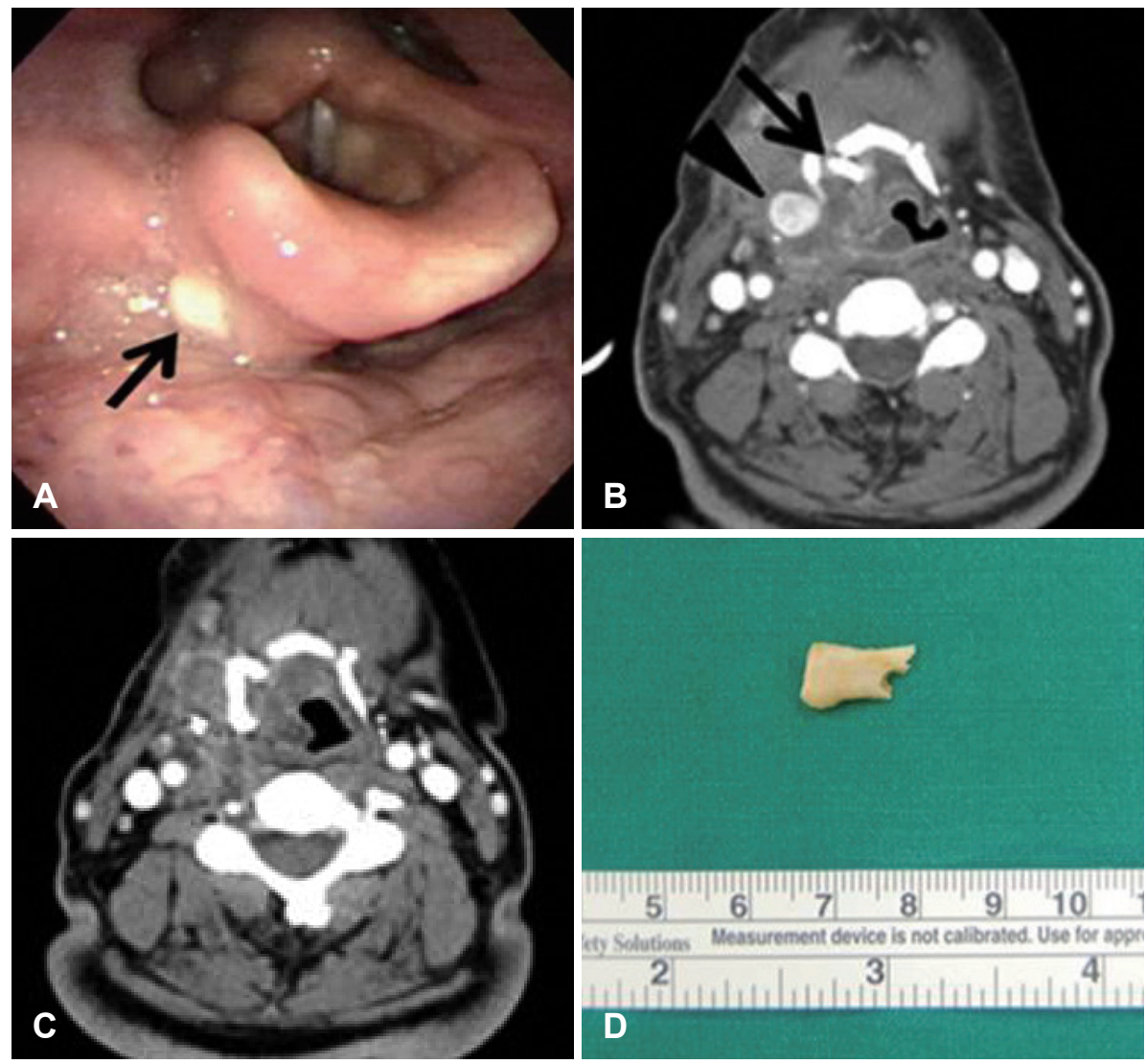

Fig. 4. Fragmented \& exposed hyoid bone. Exposed hyoid bone is noted by endoscopy ( $\mathrm{A}$, black arrow). Serial 2-week-interval CT images before (B) and after embolization (C) demonstrate the deformed and fragmented hyoid bone. Black arrow and arrowhead demonstrate the fragmented hyoid bone and contrast leakage respectively (B). Fragmented hyoid bone was extruded by itself (D).

색전술 이후 더 이상 출혈은 발생하지 않았다. 이후 퇴원하 여 경과 관찰 중 환자는 입을 벌리거나 음식물을 씹을 때 불 편함을 호소하였는데 술후 세 달째 시행한 후두내시경상 설 골의 일부 파편이 후두개곡(vallecula)에 인접하여 노출된 상 태였다(Fig. 4A). 이에 색전술 직전(Fig. 4B)과 2주 후(Fig. 4C) 시행한 경부 CT 촬영을 재검토하였을 때 염증의 파급으로 인 한 병적 골절로 추정되는 설골의 편위를 관찰할 수 있었으며 수 술적 제거를 고려하였으나 곧 설골의 일부가 입안으로 자연 배 출되었으며 현재 염증의 재발 없이 경과 관찰 중이다(Fig. 4D).

\section{고 찰}

심경부 감염의 70 80\%는 인두 감염으로 인해 발생하며 항 생제의 다양한 사용에도 불구하고 여전히 드물지 않은 질환이 다. 심경부 감염으로 인한 증상으로는 흔히 동통, 연하통, 연 하곤란, 발열이 있으며 개구 장애가 발생할 수 있다. 가장 흔한 균주는 호기성 균주로서 Streptococcus viridans, $\beta$-hemolytic streptococci, Klebsiella pneumoniae 이며 혐기성 균주로는 Bacteroides 등이 있는데 심경부 감염의 경우는 주로 복합감염의 양상을 띤다. ${ }^{4)}$ 치성 감염이 가장 흔한 원인으로 알려져 있으며, 
그 외 편도염, 침샘염, 림프절염, 중이염, 후두개염 등이 있지만 원인을 알 수 없는 경우도 많다. 기저 질환으로 심혈관 질환과 당뇨의 빈도가 높으며 폐, 간, 신장 질환이 동반되기도 하며 흡 연 또한 유발 요인이라 할 수 있다.,5) 연령별 분포는 비교적 균 등하며 여성보다 남성의 감염률이 높다.

당뇨 환자의 고혈당 상태는 말초 혈관 장애가 발생하여 혐기 감염률을 높일 수 있으며 백혈구, 대식 세포, 섬유모세포의 기 능을 저하시켜 면역력에 문제를 야기한다. ${ }^{3,5,6)}$ 본 증례에서 보 는 환자처럼 당뇨 병력이 있는 경우 폐렴간균(Klebsiella pneumoniae) 감염이 가장 흔하였으며 합병증이나 재원 기간 등이 당뇨 병력이 없는 경우보다 높다고 알려져 있는데, Lin 등의 의 연구에 따르면 당뇨 환자에서 종격동염, 패혈증, 호흡곤란 등 의 합병증이 더 빈번하게 발생하였고 재원 기간에서도 당뇨 군에서 평균 19.3일, 비당뇨군에서는 평균 13.1일로 유의한 차 이가 있었다.

$\mathrm{Lee}$ 와 $\mathrm{Lim}^{7}$ 의 연구에 의하면 수술적 치료를 시행하였던 심 경부감염 환자 중 당뇨가 있었던 19예 중 3예가 종격동염과 패 혈증으로 인한 다장기부전(multi-organ failure)으로 사망하 였으나 비당뇨군의 102예에서는 사망 없이 모두 회복되었다. 또한 Boscolo-Rizzo 등 ${ }^{3}$ 도 심경부 감염 대상자 67명 중 27명 (40.3\%)이 당뇨 병력이 있었으며 합병증 관련 인자로 당뇨 및 감염의 다공간 침범이 가장 강력한 예측 인자(predictor)임을 주장한 바, 심경부 감염 환자에 있어 합병증으로의 이환율과 치사율을 낮추기 위하여 의료진은 매우 엄격하게 혈당을 관리 하여야 한다.

부인두 공간은 뒤집어 놓은 원추 모양의 공간이며 두개저에 서부터 설골에 이르며 경계가 명확하지 않기 때문에 주위 공 간의 감염으로 인해 발생하는 2 차적인 부위가 되며 역으로 부 인두 공간에서의 감염은 지방이 빠르게 액화되어 큰 농양을

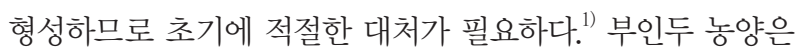
경동맥 막을 따라 종격동까지 파급되어 심각한 합병증을 유 발할 수 있으며 염증이 진행되어 동맥을 침범하게 되면 생명 을 위협할 정도의 출혈이 발생하게 되므로 그 진단과 치료는 중요하다. 부인두 공간 또는 후인두 공간의 감염의 경우 항생 제의 사용은 10 15\%에서만 효과적인 것으로 보고되어 많은 경 우 중재적 시술이나 카테터를 이용한 배농술이 요구된다. ${ }^{8)}$

증례의 경우 초출혈로 인하여 본원으로의 재내원 전까지 2 주간에 걸친 타 병원 재원 시의 임상경과를 파악하긴 어려우나 출혈이 발생하기 전까지 컴퓨터단층촬영 등 환자의 증상과 국 소 소견에 대한 좀 더 적극적인 추적관찰이 필요했던 것으로 판 단된다.

심경부 감염으로 발생한 농양에 대한 치료는 적절한 항생제 정주, 초음파 유도하에 카테터 배액관 삽입술, 수술적 치료를
통한 절개 배농 방법 등이 있으며 본 증례는 초음파 관찰하에 카테터 배액을 유도하였다. Woo 등')은 67명의 심경부 감염 환 자를 대상으로 병변의 크기가 $7 \mathrm{~cm}$ 미만의 불완전한 농양인 경우 항생제 치료가 효과적이며, 수술적 절개 방법은 완전 농 양이거나 $7 \mathrm{~cm}$ 이상의 불완전 농양인 경우, 호흡곤란 또는 패 혈증 같은 합병증이 동반된 경우, 감염 부위가 넓고 여러 부위 를 침범하였거나 48시간 충분한 항생제 투여에도 호전되지 않 는 경우 시행하는 것이 좋다고 주장하였다.

하지만 수술적 절개에 의한 배농을 시행할 경우 전신마취를 필요로 하는 경우가 많고, 술 후 경부의 반흔이 남을 뿐만 아 니라 혈관손상 및 신경손상과 같은 주변조직의 손상으로 인 한 이차적인 문제들을 일으킬 수 있다. ${ }^{10}$

초음파 유도하에 카테터 배액관 삽입술은 수술에 의한 농 양 주위 구조물의 손상을 최소화할 수 있으며 간농양, 담낭 질 환 등 내과적 환자의 치료 및 관절 내 농양, 혈종 제거 등 다양 한 질환의 치료에 이용되고 있다. 본 증례에서 사용한 pigtail 카테터는 방사선 불투과성으로 시술 후 위치의 확인이 용이하 고 삽입이 쉬운 장점이 있다. Han 등이에 의하면 카테터 배농 을 시행한 12 명의 환자 중 11 명에서 농양의 완전 관해를 보였 으며 다엽성 농양(multiloculated)에서도 효과가 있음을 확인 하였다. 또한, 17 명의 심경부 농양 환자를 대상으로 한 Biron 등 ${ }^{11}$ 은 초음파 유도하에 카테터 배액관 삽입술을 받은 환자 모두 재발 없이 치료할 수 있었으며, 평균 재원 일수는 3.1일로 서 수술적 배농술을 시행받은 환자의 5.2 일에 비해 유의하게 짧았고 치료 비용도 수술을 시행한 환자에 비해 평균 $41 \%$ 저 렴한 것을 보고하였다.

이에 기존의 연구들에 의하면 초음파 유도하에 카테터 배액관 삽입술은 비교적 경계가 명확하거나 단일엽 농양의 경우(welldefined and/or unilocular), 감염된 낭종(infected cyst), 후인 두 또는 부인두 공간처럼 보다 깊은 내장공간(visceral space) 의 경우 효과적이라 할 수 있다. 그러나 크기가 $3 \mathrm{~cm}$ 이상이거 나 다엽성 농양, 기도 압박이나 패혈성 쇼크가 임박한 경우에 는 수술적 접근법의 이득이 크다고 주장하였다.,11,12) 따라서 적 절한 상황에 따른 카테터 배액관 삽입술은 환자에게 덜 침습 적이며 안전하고 경제적인 술식이 될 수 있다.

본 증례의 경우 농양이 장기간 지속되었고 또한 비교적 넓 은 범위의 병변이 관찰되어 경부 또는 구강을 통한 절개배농 또한 고려하였다. 그러나 저자들은 당시 깊은 부인두 공간에 위 치한 단엽성의 농양이 이미 구인두로 파열되어 배액되고 있었 고, 당시의 특수한 상황, 즉 환자가 복용하고 있던 아스피린으 로 인하여 보다 광범위한 절개배농 후 당시의 활동성 출혈이 오히려 심해질 가능성, 재내원 당시 검사상 백혈구 수치가 정상 범위 등 혈액학적으로 염증 소견이 심하지 않았던 점, 또한 기 
존의 전통적 절개배농 대신, 카테터 삽입을 통하여 심경부 감 염을 보존적으로 치험하였던 본원에서의 전통적 경험 등을 바 탕으로 우선적으로는 카테터 삽입을 계획하였다. 또한, 아스피 린을 중단한 상태에서 향후 이러한 보존적 치료를 통해 증세 가 호전되지 않는 경우 즉각적인 절개를 통한 배농의 필요성을 환자 및 보호자들에게 설명하고 동의하에 치료를 계획하였다. 카테터를 통한 배농 후 출혈은 관찰되지 않았으며, 염증 증상 과 국소 소견 모두 빠르게 호전되었다.

다만 이 환자의 경우, 카테터 삽입 3일 후 다시 다량의 출혈 이 발생하였다. 이를 후향적으로 생각해 보면, 아스피린 복용 을 고려하더라도 초기에 절개배농과 같은 처치가 지연되어 환 자의 가성동맥류 형성이나 치료에 부정적 영향이 발생하였을 가능성 또한 고려할 수 있다. 그러나 출혈 전 임상증상은 빠르 게 호전되었고, 3일이라는 비교적 짧은 시간 안에 새로운 출혈 이 발생한 점, 카테터 삽입 전 이미 설골의 병적 골절과 편위가 관찰되었을 정도로 농양으로 인하여 조직손상이 심했던 점 등 을 감안해 보았을 때, 카테터로 인해 야기된 직접적 출혈이라 기보다는 타 병원에서 치료받으며 2주간 잔존해 있던 농양에 의해 상갑상동맥 혈관벽의 침윤(erosion)이 이미 발생하였을 가능성이 있을 것으로 생각된다. 또한 최근 전 세계에 걸쳐 대 규모로 수행된 다 기관 임상 연구에 따르면 술전 아스피린 복 용은 다량의 출혈(major bleeding) 위험성을 높이는 것으로 알려져 있으며, ${ }^{13)}$ 술전 치료계획의 수립에 있어 혈관벽 침윤을 사전에 정확히 예측하는 것은 쉽지 않다.

이에 저자들은 아스피린 복용하에 현성 출혈을 보이는 심경 부 환자에서 합병증의 발생을 줄이고자 향후 절개배농을 염 두에 둔 상태에서 보존적 치료방법으로 접근하였다. 또한, 후 향적으로 이러한 혈관손상으로 인한 출혈은 당시 조직손상이 심한 상태에서 수술적 절개배농을 선택하여 시행하였을 경우 에도 발생할 수 있는 바, ${ }^{10}$ 치료 방법 선택의 문제라기보다는 치 료에 뒤따를 수 있는 이차적인 합병증의 가능성이 높을 것으 로 판단한다.

동맥은 내막, 중막, 외막의 3층의 혈관벽으로 구성되며 동맥 류는 진성동맥류와 가성동맥류로 나뉜다. 진성동맥류는 3층의 막으로 싸여 있으나 가성동맥류는 3층의 막 중 내막 및 중막이 결손되어 있으며 외막 또한 소실된 경우도 있다. 가성동맥류는 주로 술후 또는 외상성 혈관손상에 의해 발생하며 심경부 감 염에서 가성동맥류는 매우 드물게 발생한다.

국외에서 발표한 연구에 따르면 인두농양의 합병증에 의한 외경동맥 가성동맥류 출혈에 관한 증례 보고가 있으며 소아에 서 발생한 경우였으나 ${ }^{14)}$ 국내에서는 아직 보고된 바가 없다. 외 경동맥의 경우 지금까지 5증례 정도가 보고된 바 인후두 절제 술, 기관 절개술, 방사선 조사, 부갑상선 절제술 등 치료 후 발생
한 경우가 각각 1 예, 이외에도 갑상선 결절에 대한 세침흡입검 사를 시행하는 과정에서 1 예가 발생하였다고 보고된 바 있다. ${ }^{15)}$

본 예는 젊은 여성에서 심경부 감염으로 인해 발생한 가성 동맥류였으며 장기간 지속된 부인두 농양과 잘 조절되지 않았 던 당뇨, 그리고 뇌졸중으로 인한 스텐트 시술과 관련된 아스 피린 복용 등이 복합적으로 관여하였을 것으로 판단하며 이 로 인한 출혈은 중재적 응급색전술을 통해 효과적으로 치료 할 수 있었다. 이에 잘 조절되지 않는 구인두 염증이나 심경부 감염이 지속되는 환자에서 갑작스런 심한 출혈이 발생할 경우 가성동맥류 기원의 출혈 가능성을 생각해야 하며, 이때 혈관 조영술은 출혈의 원인에 대한 빠른 진단과 치료를 동시에 시행 할 수 있는 매우 효율적인 치료법이 될 수 있다.

\section{Acknowledgments}

This work was supported by Pusan National University for 2 years research grant.

\section{REFERENCES}

1) Hedge A, Mohan S, Lim WE. Infections of the deep neck spaces. Singapore Med J 2012;53(5):305-11; quiz 312.

2) Lee YQ, Kanagalingam J. Bacteriology of deep neck abscesses: a retrospective review of 96 consecutive cases. Singapore Med J 2011; 52(5):351-5.

3) Boscolo-Rizzo P, Stellin M, Muzzi E, Mantovani M, Fuson R, Lupato $\mathrm{V}$, et al. Deep neck infections: a study of 365 cases highlighting recommendations for management and treatment. Eur Arch Otorhinolaryngol 2012;269(4):1241-9.

4) Song HM, Choi SH, Choi SH, Kim SY, Nam SY. Isolated microorganisms and antimicrobial resistance of the deep neck infection: a retrospective review of 76 cases. Korean J OtolaryngolHead Neck Surg 2006;49(1):66-71.

5) Kim YS, Park JH, Chun SS, Han DY, Kim JE, Lee BD. Clinical analysis of deep neck infection. Korean J Otorhinolaryngol-Head Neck Surg 2010;53(10):627-31.

6) Lin HT, Tsai CS, Chen YL, Liang JG. Influence of diabetes mellitus on deep neck infection. J Laryngol Otol 2006;120(8):650-4.

7) Lee JK, Lim SC. Deep neck infections in diabetic patients. Korean J Otolaryngol-Head Neck Surg 2006;49(3):323-7.

8) Plaza Mayor G, Martínez-San Millán J, Martínez-Vidal A. Is conservative treatment of deep neck space infections appropriate? Head Neck 2001;23(2):126-33.

9) Woo JH, Cha HE, Lee JH, Gang IG, Baek MK, Kim DY. Clinical analysis of factors affecting on treatment of deep neck Infection. Korean J Otorhinolaryngol-Head Neck Surg 2008;51(6):544-8.

10) Han KY, Lee JH, Kim JH, Kim JY, Shim BS, Song YJ. Ultrasonography guided percutaneous aspiration and drainage of deep neck abscesses. Korean J Otorhinolaryngol-Head Neck Surg 2009;52(4):354-8.

11) Biron VL, Kurien G, Dziegielewski P, Barber B, Seikaly H. Surgical vs ultrasound-guided drainage of deep neck space abscesses: a randomized controlled trial: surgical vs ultrasound drainage. J Otolaryngol Head Neck Surg 2013;42:18.

12) Chang KP, Chen YL, Hao SP, Chen SM. Ultrasound-guided closed drainage for abscesses of the head and neck. Otolaryngol Head Neck Surg 2005;132(1):119-24.

13) Devereaux PJ, Mrkobrada M, Sessler DI, Leslie K, Alonso-Coello P, Kurz A, et al. Aspirin in patients undergoing noncardiac surgery. N Engl J Med 2014;370(16):1494-503.

14) Gonda RL Jr, Gutierrez OH, Hengerer AS, De Weese JA. Pharyngeal 
Pseudoaneurysm by Deep Neck Abscess I Cheon YI, et al.

abscess with external carotid artery erosion and pseudoaneurysm. A combined radiologic and surgical management. Pediatr Neurosurg 1990-1991;16(1):21-4.

15) Celik H, Yücel C, Oktar S, Karadag Z, Ozdemir H. Iatrogenic pseudoaneurysm of the superior thyroid artery: color Doppler ultrasonographic diagnosis and treatment approach. J Ultrasound Med 2004;23(12):1675-8. 